\title{
A CASE REPORT OF PRIMARY NEURINOMA OF THE MIDDLE EAR
}

\author{
By \\ Y. TAKEI, M.D. AND T. UEDA

\begin{abstract}
From the Department of Otorhinolaryngology, Nagasaki University
\end{abstract} \\ School of Medicine. (Director: Prof. Toshiro Goto)
}

\begin{abstract}
A neurinoma was confirmed in the tympanum and attic of the reoperative case of chronic otitis media of 53-year-old female, whose right middle ear surgery 12 years ago had facial nerve paralysis of the same side immediately after the operation.

The granulation tissue filling the tympanum and the attic was solid and thick. The anterior part of the attic wall was destroyed and the dura of the middle fossa was exposed. The mastoid cavity was filled with the granulation tissue, but in these tissues neurinomatous findings was not found.

The authors suspect from the operative findings that this neurinoma might have originated from the facial nerve at its first genu, where the bone resorption was remarkable.

But the relationship between the damage of the facial nerve at the previous operation and growth of neurinoma was not clarified.
\end{abstract}

\section{\中耳に原発した神経鞘腫（Neurinom）の１例}

\author{
長崎大学医学部耳粤咽喉科学教室 (主任: 後藤敏郎教授) \\ 武井
}

\section{I. 緒言}

耳の㯵湯は他藏器に較らべて極めて稀であり，しかる そのほとえどが悪性腫瘍であつて, 中耳では癌重が最す 多く，肉腫がこれに次ぎ，内被細胞腫が稀に報告されて いる.教室の小川の集めた統計によると外耳及び中耳の 癌は本邦では69例（1958）を数え，その内訳忙界店 9 例, 外耳道癌 31 例, 中耳腔癌 14 例, 乳突腔癌 11 例, 不明 4 例である。これに対して中耳の良性埂瘍は更に少 くなく文献では外国に执いては血管腫 (Ruttin)，海綿 性血管嗹 (Heine), リンパ管腫 (Stein), 粘液線維腫 (Schwach u. Bielschowsky), 耳根治手術後の皮様躣腫 (Urbantschitsch) 等が散見されるが，本邦の文献では

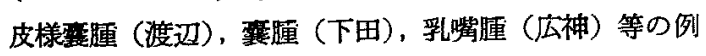
を数えるに過ぎない．

著者は最近中耳手術後 12 年目に同側敨室に原発した 願面神経 神経鞘埂 (Neurionom) と思加れる 1 例を経 験したので報告する。

$$
\begin{aligned}
& \text { II. 症 } \\
& \text { 患 者：例 } \\
& \text { 12-73 }
\end{aligned}
$$

初診: 昭和 36 年 4 月 6 日

主 訴: 右耳の悪臭耳漏

既往歴：昭和 24 年3月 Hydrosalpinx で abdominale Tubo-oophorektomie 受けた。炤和 24 年 6 月 右側慢性中耳炎で手術を受けた。

家族歴：都患はない。

現病歴：12 年前右側慢性中耳炎のため某医で手術を 受汁，術後同側の顔面神経麻痻を起こした，乞の後は特 別な耳症状はなかつたが約6力月前より何んらの誘因な く右耳漏をみるようになり，耳漏は漸次悪臬を伴うよう になつた、約 3 カ前に某医を訪れて右外耳道の㯵溜を 指摘された。その後耳漏が次第に堌加するので当科を訪 れた. 4 月“10日K入院.

全身的所見：一般状態には特別な所見は認められな w.

梅军血清检查は W.R. (緒方法)（H)，V.D.R.L. (t)， 杪田法（士）。

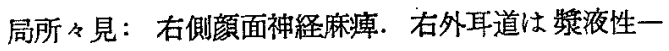
膿性分泌液中等量. 入口部上り的 $1 \mathrm{~cm}$ 深部に和いて 


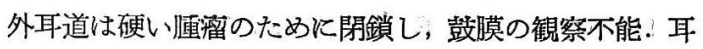

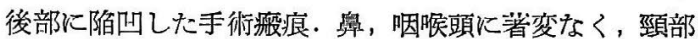
にはリンパ節の庭脹を認めない。

レ線所見：患側々頭骨の含気度は抑制 (H) で，外 耳道後壁の一部に骨破壊像が認められるが既手術である ためにとの意味は不明.

外耳道腫溜の組織検査：以上の 所見から一応癌䭪を 疑い試験切除. 䛦断は Granulom (von entzündlicher Natur)! 但し, 一般の炎症による肉芽にしては入口部に 近すぎるし及 derb にすぎる. 聅患の性質は不明のま〉 に手術を行ら.

手術時所見：4 月 14 日施行

耳後創を開くと Planum mastoideum に前の手術に 上る骨欠損あり. Mastoidhöhle は約小指頭大で肉芽組 織（粘膜の肥厚せる程度の）にて被わる. 外耳道壁は吸 収されその外下部より肉芽が発生し，これによつて入口 部は閉塞していた．外耳道の後壁より Brücke にかけ ては肉芽様の組織にて満たされる. 一見 chr. Mastoid. itis の像に見觉るが肉芽が derb でその前殖が旺んであ る点が異る。一般の Mastoiditis ではこのように derb な肉芽で満たされることはない，但し内 Kortikalis，は 保たれ Sinus, Dura の露出を見ない. Facialiswulst は 正常. Paukenhöhle は derb な肉芽にて充されていて Papillom, Krebs ほど derb ではないが，一般の炎症 性の肉芽としては硬すぎる.全耳小骨連鎖は消失. Attik は肉芽に充たされ，前壁の吸収が強く，Tuba 入口部の

図 1 手術時所見略図

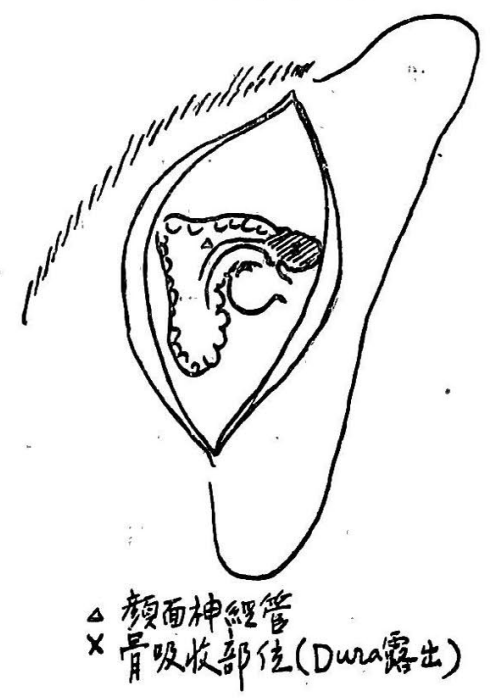

上縁が特に強く犯され, 顔面神経隆起消失し, 闪芽はそ の前方に深く侵入して Tuba の上壁と中頭蓋底との間 に約 $1 \mathrm{~cm}$ の篗みを作り, この部に小指頭大に Dura の 露出を認亦．この骨欠損部を見るまでは炎症性のものと 信じていたか，こつに至つて一般の化膿性炎症性のもの とは異なり Tumorならんと思うに至つた，但し Krebs の如く derb な組織でもなく，糊膜の肉芽様に肥厚した もの১ようであつた（図1).

Attik（前上部天蓋欠損部)，Paukenhöhle 及び Mastoidhöhle より摘出した肉芽の組織検査成績は次のよ うである。

病理組織学的検査：（本学病理学教室松岡茂教授）

i) Attik の肉芽 (写真 1)

病理診断: Neurinom

所見： spindelförmig の長い Kern を持つた細胞が 種々の大いさの Bündel を作りながらいろいろの方向に

写真 1 著明な Paradenstellung を見る 〔弱拡大〕
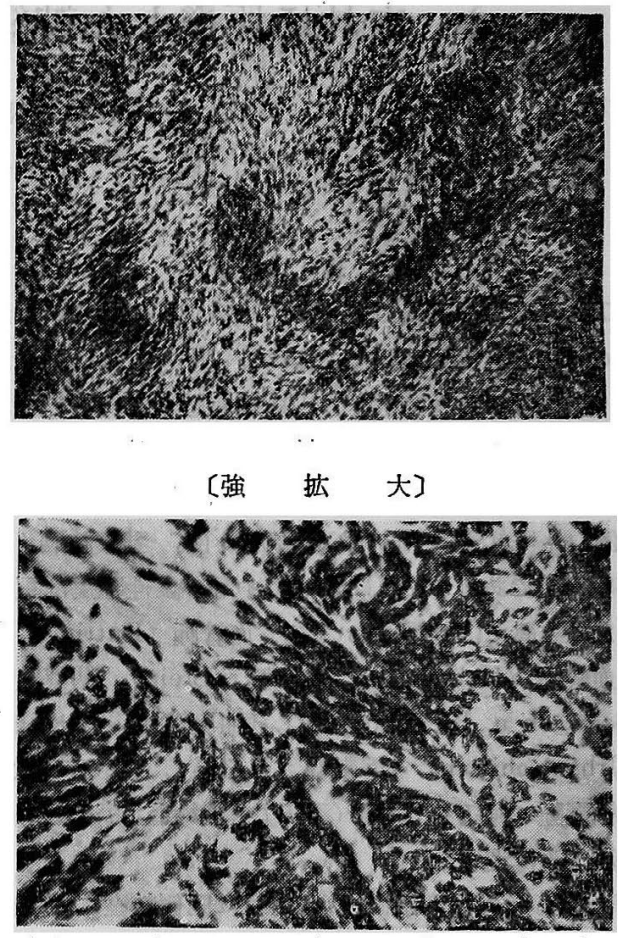

走りつ〉無秩序に 增殖したものであつて所謂 Palisadenstellung (Paradenstellung) を示す

ii) Paukenhöhle の冬芽 
病理診断：Neurinom

iii) Mastoidhöhle の肉芽

病理診䉼： entzündliches Granulom

術後経過：5月 23 日K二次的に Paukenhöhle 及び Mastoidhöhle K檤皮を行い，耳後創は鹤察のため開放 のまっとした，耳内の表皮化は容易に完成して6月16 日退院.

\section{III. 考按}

1882 年 Recklinghausen は皮简に発生する多発性絍

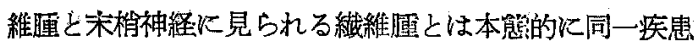
なることを確め，これを神経瀻維腫症 Neurofibromatose と称克，一般には Recklinghausen 氏病と呼ばれ た。1910年 Verocay は本腫瘖が末梢神経の Schwann 氏靬細胞の增殖を主体とするるのであることを明らかに し，神経鞘腫（Neurinom）と名つけた，組䢂学的には Schwann 氏鞘細胞から発生した長紡䤵形の細胞が束状 をなし綻横に走り，細胞檬も紡錘形で，相接する細胞が

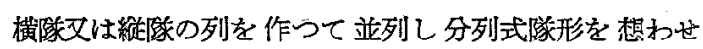
る.この細胞並びに核の配列状態を観兵様配列 Parad€nstellung 㕛は梱状配列 Palisadenstellung とい〉, 本 缰瘍に特異なるのとされている。

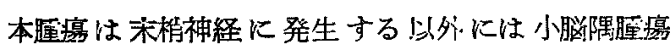
Kleinhirnwinkeltumor として発生し, 単独に N. acusticus のみにも発生する. Schwann 民䩗を有する神経 織維は脳脊骮神経（嗅神経之視神経を除く）と交感神経 てあるからこれ等は発生母地になり得る条件を持つて

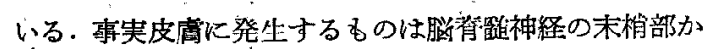
発生し，文胃腸壁に生ずるものは交感神経の未悄部か ら発生すると見做されている。従つてこの症例に扣いて は，鼓室内に発生母地を症めるならば三叉神経の外覚緎 踓, 内頸動脈神経叢の分枝，及び舌咽神経の分玟によつ

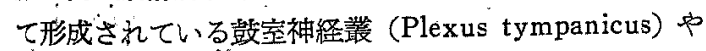
唼菜神経 (Chorda tympani) 等も一応は考慮されなけ ればならないが，その骨使収変化の部位と文献に拈ける この種の Tumor の発生部位からみて N. facialis の神 経鞘がら発生したと見做すが妥当かと思ら。

中耳に関係ある Neurinom の赫告例としては鏶富 (1953) 加内外の文献加自例を加关て 15 例集めている
(本邦例は大西 (1937)，鍵富の 2 例)，これ等の Neurinom は N. fscialis の骨管中の 水平部及び下行部より 発生して敖室，乳突腔及び外耳道に及えでいる。本例は 骨融解の最も著しい部位より推定すれば Facialiskanal の Ite Knie の附近より発生したと見るが要当之思う。 この例では12 年前に Mastoidop. を受けその酯後に Facialislähmung を起こしているが，手術による損賃 の多い Aditus 部位の Facialiswulst には骨壁に变化 が見られないことから，手術に上る損甥と Neurinom の発生との間の関係は不明である，交献に見られるよう にとの発生部位は一定なず，文携賃部位とは限つていな いことから見ても手術による損侮部との位置的関係は必 ずしも一致しなくてもよい。

Mastoidhöhle の肉芽は戥室に Neurinom が発生し たつめに二次的に起つた炎症性の Granulom と考える のが妥当と思われる。

\section{IV, 結語}

53 文の家婦.中耳手術後 12 年目に同側豉室に Neurinom の発生を見た。この発生部位心顔面神経第 1 Knee の部位より発生したと思われるが，この例は初め の手術後顔面神経麻㾇を起こしているからこの揁傷と堙 瘕の発生との関係は明らかでない。

\section{文献}

1) 後藤郎：耳奥咽喉科学上巻, 医学甾院、2)公 神伊藤：中耳乳嘴嗹の癌变性, 巩奥臨, $20,2,349$, 1925. 3) 渡辺網应: 乳嘴篮内9 Dermoid K就い

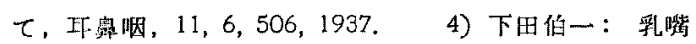
突起风に発生したる大なる哥腫の一侧，日耳鼻，33，5， 324, 1927.5）大西克保：顏面神経麻瘦を伴いたる 㯋面神経線維腫, 耳奥咽, 10,5,420,1937。6) 鍵富

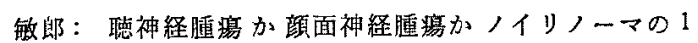

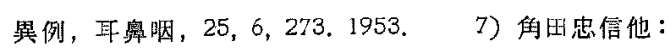

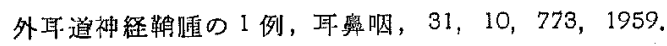
8) 小川清他: 外耳道中耳の癌に就て, 長崎医誌, 33, 7, 748, 1958. 9) Willis. R.A.: Pathology of Tumors

（原稳到湝 $=$ 昭和 36.7.22 日） 